\title{
The Impacts of Health Care Evaluations on the Well-Being of Low-incomers
}

\author{
Os Impactos das Avaliações do Cuidado de Saúde no Bem-Estar da Baixa Renda
} \\ Lilian Tellini ${ }^{1}$ \\ (D) https://orcid.org/0000-0002-8966-9434 \\ Andre Torres Urdan ${ }^{1}$ \\ (iD) https://orcid.org/0000-0002-4816-0973 \\ Sonia Francisca Monken ${ }^{1}$ \\ (D) https://orcid.org/0000-0002-5063-8956 \\ Flavio Santino Bizarrias ${ }^{1}$ \\ (D) https://orcid.org/0000-0001-5574-7820 \\ Marcelo Moll Brandão ${ }^{2}$ \\ (D) https://orcid.org/0000-0002-8593-734X
}

Universidade Nove de Julho, Programa de Pós Graduação em Administração, São Paulo, SP, Brasil ${ }^{1}$ Universidade Federal do Espirito Santo, Programa de Pós-graduação em Administração, Vítória, ES, Brasil² 


\title{
Resumo
}

Há uma chamada forte por pesquisas de marketing que contemplem os impactos de bens e serviços no bem-estar do consumidor, o que ganha mais vulto quando se trata de pessoas de baixa renda (Base da Pirâmide). Este artigo articula um Modelo Conceitual das relações entre avaliações de serviços de cuidado da saúde e o bem-estar do cliente, surgido de uma adaptação do melhor dos modelos comparados por Brady et al. (2005). Uma amostra de pacientes de baixa renda, egressos de quatro unidades de saúde pública, de atenção primária, da cidade São Paulo, foi reunida. A modelagem de equações estruturais suportou as hipóteses que ligam Qualidade Percebida e Valor Percebido, Qualidade Percebida e Satisfação, Satisfação e Bem-Estar Individual. Expressivos 35,1\% da variância do Bem-Estar Individual são explicados pelo Modelo. Emergiu uma relação positiva (ao invés de negativa) entre Sacrifício Percebida e Valor Percebido, contrariando a concepção clássica. Esses achados empíricos são confrontados com a literatura. Por fim, implicações científicas, gerenciais e políticas são expostas.

Palavras-chave: serviços; cuidado de saúde; baixa renda; bem-estar individual; antecedentes.

\begin{abstract}
There is a strong call for marketing research that looks at the impacts of goods and services on consumer wellbeing, which gains greater momentum when it comes to low-income people (Bottom of the Pyramid). This article articulates a Conceptual Model of the relations among evaluations of health care services and the well-being of the client, that arises from an adaptation of the best of the models compared by Brady et al. (2005). A sample of low-income patients, leaving care public health units in the city of São Paulo, was gathered. The structural equations modeling supported the hypotheses that link Perceived Quality and Perceived Value, Perceived Quality and Satisfaction, Satisfaction and Individual Well-being. Expressive 35.1\% of the Individual Welfare variance are explained by the Model. A positive (instead of negative) the classic conception. These empirical findings are confronted with the literature. Finally, scientific, managerial, and political implications are exposed.
\end{abstract}

Keywords: services; health care; low income; well-being, antecedents.

JEL Code: I3, I14, D31. 


\section{Introdução}

The services activities are expanding worldwide, compared to industrial and agricultural activities (Ostrom et al., 2010), but doubts arise about the type and magnitude of the impacts generated by that expansion on humankind (Bitner \& Brown, 2008). One of those possible impacts concerns wellbeing, a construct recognized as fundamental in modern societies (Ostrom, Parasuraman, Bowen, Patricio, \& Voss, 2015). For those persons that have less and much less, well-being represents a huge challenge, as they needs, many of them basic (e.g. food, education, health), are not fully met (Prahalad, 2010). It is believed that services have the potential to improve the lives of the low-incomers (Anderson et al., 2013). It is of great social and managerial interest to advance the understanding of the results generated by services targeted to low-incomers (Gebauer \& Reynoso, 2013). This priority becomes even crucial in the case of Health Care Services (HCS) due to: (a) the frequently difficulty free of charge access to them and the constrained financial resources that stratum has to pay for them (Prahalad, 2010); (b) the painful state that any individual has to put up with when deprived of appropriate HCS. The total health care spending in the world's major and measurable countries is expected to reach astonishing $\$ 8.7$ trillion dollars by 2020, up from $\$ 7$ trillion dollars in 2015 , following an expansion rate of this expense estimated to be of $4.1 \%$ in 2017-2021, a leap from only 1.3\% in 2012-2016 (Deloitte, 2018).

In Brazil, the Federal Constitution of 1988 instituted health as a universal right and a duty of the State, and accordingly brought the national Unified Health System (initials SUS, in Portuguese) (Gouveia, 2004). The principles of SUS includes equity, completeness and universality, that is, equal access to all HCS is guaranteed for everyone in the Brazilian territory, regardless of the personal financial condition (Barbosa, 2013). The SUS costs 3.8\% of the Brazilian Domestic Gross. The private system is responsible for $54 \%$ of total health expenditure in Brazil, covering $25 \%$ of the population (Giovanella et al., 2018).

The low-incomers in Brazil usually uses only HCS provided by the SUS. This system has worsened with the ongoing Brazilian crisis (lasting since 2014), that refrain the public budget devoted to HCS and triggered millions of layoffs, many of them representing the loss of a private health insurance (that was provided by the employer or was paid by individuals whose then decreased income was insufficient to bear the expense). In fact, extreme poverty grew throughout Brazil from 2014 to 2017: of the 27 states of the country, 25 had more families living in misery. Nine states reached a record level on the proportion of miserable families on 2018 (Bôas, 2018).

This upturned demand associated to the compressed supply of public HCS probably negatively influence the clients' experience. Therefore, research should be undertaken to effectively describe and explain the consequences of such HCS, including those on the well-being (Sweeney, Danaher, \& McColl-Kennedy, 2015). Moreover, the recognition of the implications of social-economic classes for public health, based on the results of several researches, comes at least since the 1960s (Witt, 1967). Implications that comprise both de behavior of the population and the behavior of health personnel.

The concept of well-being involves quality of life, satisfaction with life, an array of diverse positive and negative effects on the individual, and represents a subjective indicator of happiness (Diener \& Diener, 1995; Diener, Emmons, Larsen, \& Griffin, 1985). Well-being, as one of the central values for humankind, should be addressed as a potential consequence of traditional service evaluation constructs, like satisfaction, perceived value, and perceived quality.

From this background comes our research question: Are the evaluations of HCS (satisfaction, perceived sacrifice, perceived value, and perceived quality) able to influence individual well-being of low-incomers? Then, this paper objective is to propose and test some hypotheses about the potential impacts of HCS evaluations on well-being at the individual level of low-incomers. 


\section{Literature Review and Hypotheses Development}

This section reviews the literature about the domains, constructs and relationship mentioned in the Introduction. First, HCS is characterized and its relevance is demonstrated. Second, the low income stratum is defined and its proportion in the Brazilian population is pointed out. Third, a nomological network encompassing perceived sacrifice, perceived value, perceived quality, satisfaction - on the realm of HCS - and well-being is gradually constituted, bring forth a set of hypotheses. Fourth, we integrate the hypotheses on a Conceptual Model to be empirically tested.

\section{Health care services}

HCS comprehend a diversity of services, that include prevention and treatment of diseases and increasingly follow an holistic approach, which implies attention to broader aspects of well-being (N. Singh, 2008). In general HCS are a relatively pure type of services, as their offerings typically incorporate smaller proportions of tangible goods (J. Singh, 1991). The effectiveness of HCS requires their adaption to the patients (starting with the diagnostic) in an individualized way (Berry \& Mirabito, 2010), as much as possible, which is a managerial and professional challenge.

Among the main characteristics of HCS (also shared by almost all other services) deserve mention: (a) intangibility, (b) inseparability of the provider from the consumer, since services tend to be at least partially produced and consumed simultaneously; (c) client participation, as he/she gets involved with procedures performed to service him/her (J. Singh, 1991).

Within the huge domain of services, HCS stick out by their aptitude to deliver highly desirable benefits to everyone's lives (Ostrom, et al., 2015). The relevance of human HCS has been a longstanding interest among researchers, because of their transformative potential (Anderson et al., 2013), as they can be decisive to preserve life and avoid death or, at the minimum, to alleviate suffering.

Towards understanding the intersection, of HCS and Low-Income People, focused in this paper, the next section deals with this last domain.

\section{Low-income people}

The literature is full of discussion and divergences about what is a low-income people. Prahalad and Hart (2002) coined the acronym Bottom of the Pyramid (BoP) and included on it people living, at that time, on less than US $\$ 2$ a day. Some years ago, two-thirds of the world's population were believed to live on less than nine dollars a day (Fisk et al., 2016), which is a very restricted budget, if not a low income.

The Brazilian Economic Classification Criteria (BECC) is widely adopted by companies and marketing research agencies (Brazilian Market Research Association, 2016). On the BCCEE, the lowincomers are those pertaining to the classes D-E, that totaled $27,0 \%$ of the population, with an average house income of just 768 reais ( 207 dollars) monthly. From 2003 to 2010, a considerable number of lower class Brazilians rose to the middle class, although a substantial proportion of the population continued to strive in the BoP (Neri, 2012).

The Bolsa Família Program (PBF) is a federal Brazilian initiative, consisting of conditional cash transfer, aiming at poverty alleviation and reducing the intergenerational transmission of poverty (Chitolina, Foguel, \& Menezes-Filho, 2016). At present, PBF stipend is granted to families classified

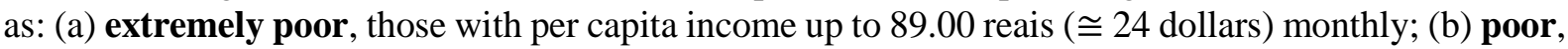
those with per capita income between 89.01 and 178.00 reais $(\cong 48$ dollars) monthly, provided they have children or adolescents from 0 to 17 years. The PBF is reaching, on 2018, almost 50,0 million of inhabitants living in 13,8 million households. For sure, people classified as extremely poor and poor in the PBF are low-incomers, and they represent around $21 \%$ of the Brazilian population (Marchesini, 2018). 
On another vein, low-incomers in Brazil are the people living in a household that collectively earn up to three monthly national minimum-wage. We took this threshold in this paper, that is the more inclusive of people among the alternative criteria here mentioned. This rationale makes sense as HCS are generally an expensive burden for Brazilians, even for those that earn up to three minimum-wages. Also, it is well recorded that poorer families have more sons, entailing more people in the household living with, at the maximum, three minimum-wages.

The low-incomers make up a fertile field of research, emphasized by Fisk et al. (2016), given their many unmet fundamental needs in various dimensions of live, including health. Rojas (2015) highlights that "The concepts of poverty and of well-being are highly intertwined; however, there is little research on how specific conceptions of poverty relate to people's well-being" (p. 317). This enormous strata call for advances and new avenues to help alleviate so many distresses, which include incorporating such people in better service systems. This journey also means huge market opportunities for organizations that can competitively entrepreneur on it. Until now, however, in general the lowincomers make considerable sacrifices striving for the benefits that they need and want; benefits that are eventually, in many and many instances, not obtained. In this sphere, we now turn to the nexus of health care services evaluations and well-being.

\section{Health care services evaluations and well-being}

For developed countries, there have been measurements and relationships around Well-Being and socio-economic strata. For instance, in a longitudinal research, the overall Well-Being score of lowincomers in the United States and Great Britain significantly lags behind that of the highest income group (Manchin, 2011), as well as the physical health, the healthy behaviors and the access to basics were all worse for those low-incomers. Such kind f evaluations are scarce or absent for developing countries like Brazil.

In another front, an empirical comparison of four service evaluation models (Figure 1) traditionally referred in the Consumer Behavior literature- was undertaken by Brady et al. (2005). They conducted a survey of users from five countries (Australia, Hong Kong, Morocco, The Netherlands, United States), spanning health care, fast-food restaurant, retail, and airline. All the models have behavioral intention as the main dependent construct and each one of them incorporate perceived sacrifice, perceived value, perceived quality and satisfaction with distinct relationships. The Model 4, labeled Comprehensive, presented the best fitting across all countries and settings and, for this cogent reason, it is appropriated in this paper. 


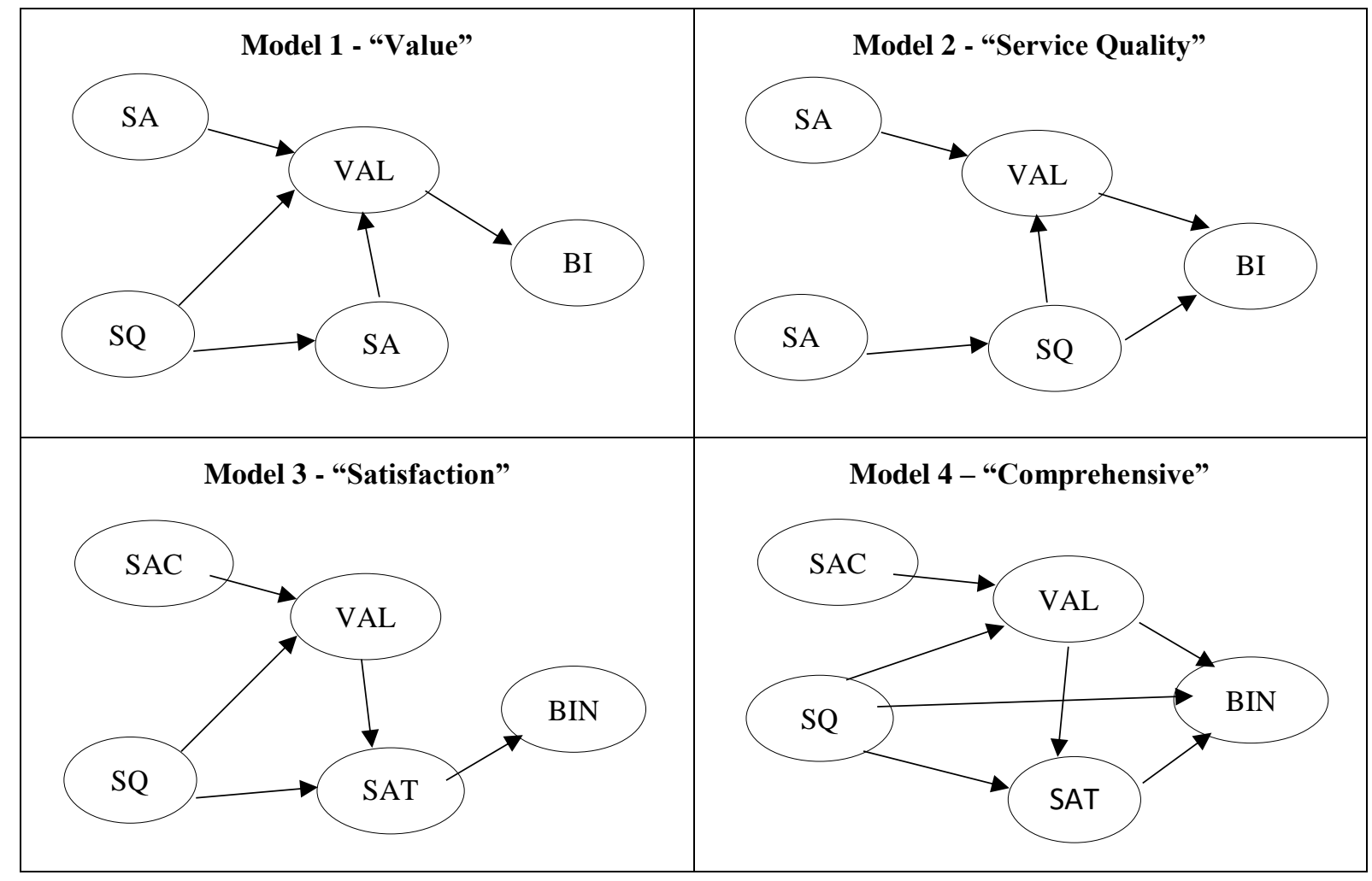

Figure 1. Four Service Evaluation Models, Widely Referred in the Literature

Descriptions - SAC: sacrifice; SQ: service quality; SAT: satisfaction; VAL: value; BI: behavioral intentions. Source: Brady, M. K., Knight, G. A., Cronin, J. J., Jr., Tomas, G., Hult, M., \& Keillor, B. D. (2005). Removing the contextual lens: A multinational, multi-setting comparison of service evaluation models (p. 218). Journal of Retailing, 81(3), 215-230. https://doi.org/10.1016/j.jretai.2005.07.005

However, we speculate that the powerful nature of HCS targeted to low-incomers means that its evaluations could affect - beyond the behavioral intentions - the individual well-being. Low-incomers depend severely on HCS, as they are often more vulnerable to diseases and suffer more treating and recovering from them. The potential impact of HCS is reinforced by the fact that, around the world, a great portion of these individuals do not have plain, nor adequate, access to them (Bhatnagar \& Grove, 2014). Therefore, such assistance could exert an expressive impact on the assisted that belongs to the BoP. This background guides the hypotheses development that follows.

Well-Being should be national priority for Brazil. On the 2016's World Ranking of Human WellBeing at the country level, Brazil appears only at the 94th position out of 155 countries, lagging behind seven other Latin American countries: Uruguay (40th), Cuba (61st), Chile (65th), Argentina (67th), El Salvador (73th), Costa Rica (75th), and México (86th) (Kerk \& Manuel, 2008; Sustainable Society Foundation, 2017).

In the same vein, the provision of HCS for low incomers is a constant challenge for governments, not only for the need to invest, expand and manage huge welfare systems, but also for the sustainability of those people, which have little or even no formal education, are often located in peripheral neighborhoods and remote places (Giovanella et al., 2018; Ostrom et al., 2015). Such characteristics hinders access to health organizations and services and make reduce the adherence to therapeutics, impacting on community and individual well-being

For itself, well-being conceptual intricacy is blatant from its core around personal subjective happiness with the live (Diener \& Diener, 1995). At the same time, the links between HCS evaluation and well-being, although often and since long time mentioned, still requires clarification and quantification. That is the scientific gap to which this paper aspires to contribute, because of its theoretical, managerial and social substantive potential implications. To do so, we move to the hypotheses outlining. 


\section{Perceived sacrifice and perceived value}

Sacrifice is something that is offered in exchange for something that one wants to acquire, be it goods and/or services, to obtain some benefits (Heskett, Sasser, \& Hart, 1990; Zeithaml, 1988). Perceived sacrifice represents the consumer's subjective perception of the costs associated with the acquisition and use of a solution (Cronin, Brady, Tomas, \& Hult, 2000), taking into account monetary (price components) and non-monetary costs (e.g., time and energy) of an experience (Boksberger \& Melsen, 2011). The press often reports, on the Brazilian landscape, intense sacrifices for those that depend on SUS: long queues at hospital emergency departments, stretchers and beds with patients on the corridors, lack of doctors and even medicines, crucial and expensive equipment out of order (Jurberg, 2008).

The perceived value of a product/offering (services and/or goods) is determined by the difference or ratio between gains and losses or, in a slightly different form, the benefits received and the sacrifices made (Brady et al., 2005). Here we opt to the ratio formula. A combination of perceived monetary and non-monetary costs makes up the perceived sacrifice by the consumer. In turn, the perceived sacrifice negatively affects the perceived value (Boksberger \& Melsen, 2011).

The perceived value of HCS is based on what the customer conceives as the benefits received (which somehow improved his/her health) relatively to the sacrifices that, in turn, he/she regard that had to shoulder (Berry \& Bendapudi, 2007). For the consumer, it is easier to estimate the value of something visible (e.g, the durability of a smart phone), but a great deal of HCS results are invisible. This makes the value estimation of such services harder to do, except perhaps in more critical diseases (e.g., a heart attack) (Sweeney et al., 2015). Besides, perceived value in services greatly involves the client's experience when interacting with the professionals and organization to receive the offering (Voss, Parasuraman, \& Grewal, 1998). This many reasons turns perceived value in HCS "difficult to understand and use properly" and "relatively little measured" (Pedroso \& Malik, 2012, p. 2758).

Perceived sacrifice is commoxz as a negative and direct antecedent of perceived value (Brady et al., 2005), albeit Leclerc and Schmitt (1999) argue that such sacrifice just indirectly influences perceived value. That direct relationship seems more logical (as perceived sacrifice is the denominator in the equation of perceived value), rationale that leads to the first hypothesis.

H1: In HCS, Perceived Sacrifice negatively affects Perceived Value.

The numerator in the perceived value ratio of HCS exhibit the cure of diseases and/or their prevention, the latter being more widespread today, given its lower costs (both monetary and nonmonetary) for the payers (being them the patient, a HCS plan or the government) (Berry \& Mirabito, 2010). Customer satisfaction arises when the offering by a supplier match or surpass the consumer needs and wants (Oliver, 1993) or expectations (Zeithaml \& Berry, 2003). In HCS, consumer satisfaction is a cognitive assessment of a wide range of explicit attributes of the diagnostic and treatment received, in addition to a general emotional disposition, during a service episode (J. Singh, 1991). Given the prominence of the perceived value of HCS to the user, it should directly impact his/her satisfaction. As so grounded, a second hypothesis is derived.

H2: In HCS, Perceived Value positively affects Satisfaction.

\section{Perceived quality}

Perceived quality is based on the difference between the excellence or superiority of an offer relatively to the customer expectations and the competitors' offers (Urdan, 2001); this formula is similar to that of satisfaction, but the evaluated domain is different. Perceived quality can also be interpreted as the recognition by the user of the competent efforts of a supplier to get things right, as necessary and appropriate for him/her (Pedroso \& Malik, 2012). 
Perceived quality of HCS "is a feeling that one has been well treated", according to Vecina and Malik (2012, p. 328), Such quality encompass three categories: results, process, and structure (Donabedian, 1988). The results are the consequences of the services delivered to the patient. The process refers to the procedures set in motion by the professionals to serve the patient. The structure consists of facilities and the physical environment in which the services are provided. The pressure for quality in HCS is as high as in other areas, if it is not higher. In the best model on Brady et al. (2005), perceive quality is an antecedent of perceived value, as a positive contributor to the numerator in the ratio of this second construct. Thus, a third hypothesis is established.

H3: In HCS, Perceived Quality positively affects Perceived Value.

\section{Satisfaction}

Satisfaction with HCS, compared to other service types, is more difficult to reach because many people search them when they are already sick. This frequently means that HCS, although necessary, are not desired (Berry \& Mirabito, 2010). The consumer does not want to use these services spontaneously, but have to out of a physical or mental necessity (Berry \& Bendapudi, 2007). A complicating factor for HCS is that, if poorly provided, they can lead to more suffering and, on the borderline, death. The solution of these adverse potential consequences and the associated risks really depends on quality and, particularly, on perceived quality. Summing up, in HCS, the client satisfaction should depend heavily on perceived quality (Akhade, Jaju, \& Lahke, 2013). This logic generates the forth hypothesis .

H4: In HCS, Perceived Quality positively affects Satisfaction.

\section{Well-being}

Many decades ago, well-being was already conceived as the level of quality of life, i.e. the extent to which pleasure and satisfaction characterize human existence and the extent to which people can avoid the ills of life that prevent them from a good and pleasant life (Andrews, 1974). On a succinct mode, well-being is a synonymous with happiness (Sirgy et al., 2006) or satisfaction with life (Diener \& Diener, 1995; Diener, Inglehart, \& Tay, 2013). In all cases, however, well-being represents a state of general contentment felt by the individual (Diener, Suh, Lucas, \& Smith, 1999). As a broad concept that has been studied in several fields, well-being has been presented with many characteristics and dimensions. The list includes wealth (Diener \& Biswas-Diener, 2001), availability of goods and services (Goldschmidt, 1972), positive events and quality of life (Sirgy et al., 2012), materialism (Burroughs \& Rindfleisch, 2002), work-life balance (Sirgy \& Lee, 2016).

Anderson et al. (2013) highlight the role of services to increase the well-being of people and society. Anderson and Ostrom (2015) ask for more research on well-being in contexts of poverty. The low-income people, due to the lack of resources, become vulnerable to inferior services or, in the worsen case, are partially or totally deprived of them. Serving the demands of the BoP may be complicated by the fact that it is more difficult to engage these less schooled consumers in complex service systemswhich are typical of HCS - and deliver services that depend upon strict cooperation from the patient. To provide experiences able to improve their well-being, a network of many resources and agents has to be adapted to the profile of the HCS users at the BoP, which is not the case, too commonly.

In the BoP, persons strongly (a) relies on the public HCS, renowned by its deficiencies and constraints, (b) have a disadvantageous socioeconomic position and (c) strive with many unmet needs. Then, the user satisfaction with HCS maybe be insufficient to affect well-being, On the contrary, satisfactory HCS can be so relevant and welcome by this suffering layer that a direct contribution to wellbeing would happen (Prahalad, 2010). As so, especially for a low-incomer, the greater the satisfaction with HCS, the greater could be her/his well-being. Therefore, we put forth the fifth hypothesis.

H5: Satisfaction with HCS positively affects Well-being. 


\section{The conceptual model}

All the previous hypotheses - H1 to H5 - are schematically integrated in the Conceptual Model shown in Figure 2. But we did not find any empirical evidence supporting such Model on the academic literature. To get over this void, we drive to the method of an empirical investigation.

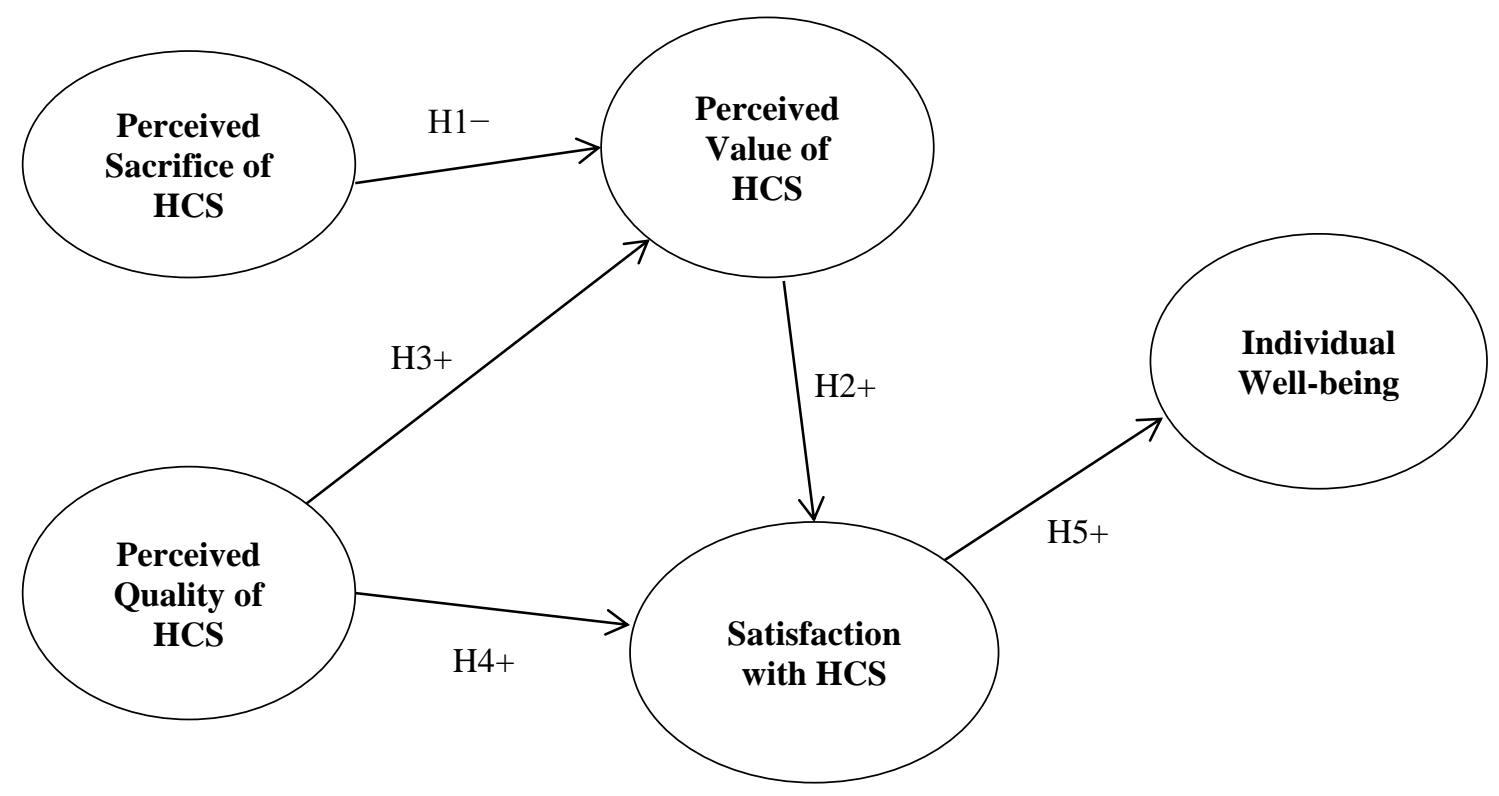

Figure 2. Our Conceptual Model

Source: The authors.

\section{Empirical Method and Procedures}

In order to test the proposed Conceptual Model, a quantitative and descriptive design was undertaken (Malhotra, 2009). A survey was used to measure its multiple constructs (Cooper \& Schindler, 2003; Freitas, Janissek, Moscarola, \& Baulac, 2002).

\section{Population and sample}

The target population was low-income users of Primary Health services provided by public clinics, in the city of São Paulo, the largest in Brazil. Such Primaries generally are the initial contact of a symptomatic patient with the health system, where he/she can get low complexity services from diverse professionals.

At a first step, we performed a stratified sampling of the public clinics in São Paulo city, drawing one clinic (from a list of its clinics) in each of the four zones of the city (Kerlinger, 1980). We came up with clinics in the neighborhoods of Americanópolis (South Zone), Artur Alvim (East Zone), Mandaqui (North Zone) and Perus (West Zone). All these clinics are integrated, i.e., they also offer Ambulatory Medical Care (medical consultation by appointment) and perform services related to the Family Health Strategy Program. Anyway, all their services are of primary care, low-complexity ones that goes from prevention (e.g. vaccinations) to the ongoing administration of chronic diseases (e.g., diabetes) and palliative support (relief from the symptoms and stress of a serious illness, like multiple sclerosis). At those clinics, cases identified as medium- or high-complexity are referred to public hospitals or private ones that are contracted by the national Unified Health System (SUS). 
The minimum total sample size was specified as 300 users, resting on Freitas, Oliveira, Saccol, $\&$ Moscarola (2000, p. 107), as an often very good number in terms of "the chances of obtaining values or results in line with the reality". Then, at a second step, on a convenience sampling procedure, the users were personally asked to take part in the research (i.e., answering the questionnaire) when leaving one of those four unit, just after receiving any kind of service. This way, we captured the specific evaluations of a real and pretty recent HCS experiences, instead of the memories about a distant service or an impression in respect to a hypothetical situation.

We regarded as low-incomer a person pertaining to a household with total earning of up to three

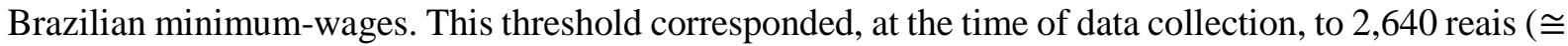
702 dollars) monthly or 88 reais ( $\cong 23$ dollars) daily, for all the people in the household. A filter question, about household income, was inserted at the beginning of the questionnaire and through it only the specified low-incomers continued up to the end (and, afterward, were included in the sample).

\section{Measurement and data collection}

We measured the constructs: (a) Satisfaction (S) with a scale from Dagger and Sweeney (2006); (b) Perceived Quality (SQ) with a scale from Brady et al. (2005); (c) Perceived Sacrifice (SAC) with a scale from Cronin, Brady, Tomas, and Hult (2000); (d) Well-being (WB) with a scale from Diener, Emmons, Larsen and Griffin (1985).

The scales inserted in the questionnaire (except that of well-being) were checked through translation and back translation. A specialist confirmed the translations of the scales to Portuguese initially jointly done by the authors of this paper. Next, another specialist performed the back translation to English. The original text in English and the text translated to this language from Portuguese was quite similar in all the examined scales. The scale of well-being (Diener et al., 1985; Kobau, Sniezek, Zack, Lucas, \& Burns, 2010) did not need translation, since it is provided in several languages, including Portuguese (Diener, 2010). All the scales use a Likert-type scale with 5 points, ranging from 1 You totally disagree, to 5 You totally agree. This structure was able to generate a broad measurement and to capture the characteristics of the investigated constructs on the view of the targeted population (Zambaldi, Costa, \& Ponchio, 2014).

The questionnaire, besides the household income filter question and the scales, have a short general profile battery (age, sex, and region of residence in the city).

A pre-test of the questionnaire was carried out to observe both the interviewee's difficulties and to get a preliminary idea about the univariate statistics. Although no mistake nor a great difficulty were detected, the learning drove an slightly modified version of the questionnaire. Of the 15 elements in the pre-test, half were in the 15 to 40 years bracket, half were 41 to 67 years. In terms of household income, $77 \%$ of them were earned between $\mathrm{R} \$ 1,301.00$ and $\mathrm{R} \$ 1,800.00$ per month. $75 \%$ of the respondents were women.

The research project and the final version of the questionnaire was submitted to the federal Plataform Brasil (Ministério da Saúde, 2012; Norma operacional Nº 001, 2013; Resolução $n^{\circ}$ 466, 2012) and approved by the Research Ethics Committee (REC) of the authors' university, as they comply with the guidelines on regulated ethical and legal aspects of research involving human-beings in Brazil.

The questionnaire was printed out and personally administered from December 26th, 2016 to January 31st, 2017. The interviewers - the first author of this paper and an assistant - took note of the answers, preventing difficulties that could be caused by low schooling (which is often associated to low income) and/or any disabilities (physical or mental) aroused by a chronicle or acute illness.

\section{Data analysis technique}

We applied Structural Equation Modeling (SEM), as a confirmatory multivariate statistical technique guided mainly by theory, rather than by empirical results, able to simultaneously deal with 
multiple regressions (Hair, Hult, Ringle, \& Sarstedt, 2014). The Kolmogorov-Smirnov (KS) test of normality on our database revealed many variables without this characteristic (Hair et al., 2014). For this reason, to implement the SEM, we opted for the Partial Least Squares (PLS) method, based on correlation matrix, that tolerate variables without a normal distribution (Chin, 1998, Hair et al., 2014). We used the software SmartPLS 2.0 (Ringle, Wende, \& Will, 2005).

Several indicators were examined around the SEM performed for the Conceptual Model with our sample of HCS' users. These indicators and respective criteria are on Table 1, comprising both the measurement models for each construct and the structural model as a whole (Hair et al., 2014).

Table 1

Indicators and Respective Criteria Examined on the Structural Equation Modeling for the Conceptual Model

\begin{tabular}{|c|c|c|}
\hline Indicator & Purpose & Criteria \\
\hline AVE & Convergent validity & AVE $>0.50$ \\
\hline Cross loads & Discriminant validity & $\begin{array}{l}\text { Higher load values in the original } \\
\text { latent variables than in others. }\end{array}$ \\
\hline Fornell and Larcker Criteria & Discriminant validity & $\begin{array}{l}\text { The square roots of the AVEs larger } \\
\text { than the correlations of the } \\
\text { constructs. }\end{array}$ \\
\hline \multirow{2}{*}{$\begin{array}{l}\text { Cronbach's Alpha and Composite } \\
\text { Reliability }\end{array}$} & \multirow{2}{*}{ Reliability } & $\mathrm{AC}>0.70$ \\
\hline & & $\mathrm{CC}>0.70$ \\
\hline Student $t$ test & $\begin{array}{l}\text { Evaluates the significance of the } \\
\text { correlations and regressions }\end{array}$ & $\begin{array}{l}t \geq 1.96 \text { or } \\
5 \%(t \geq 1.79, p \leq 0.05)\end{array}$ \\
\hline $\begin{array}{l}\text { Pearson Determination } \\
\text { Coefficient }\left(\mathbf{R}^{2}\right)\end{array}$ & $\begin{array}{l}\text { Evaluate the portion of the variance } \\
\text { of an endogenous variable that is } \\
\text { explained by the structural model. }\end{array}$ & $\begin{array}{l}\text { In social and behavioral sciences, } \\
2 \%<\mathrm{R} 2 \leq 13 \% \text { is a small effect, } \\
13<\mathrm{R} 2 \leq 26 \% \text { is moderate, } 26 \%<\mathrm{R}^{2} \text { is } \\
\text { large. }\end{array}$ \\
\hline Effect size $\left(\mathbf{f}^{2}\right)$ or Cohen indicator & $\begin{array}{l}\text { Evaluates how useful each } \\
\text { construct is for the adjustment of } \\
\text { the model }\end{array}$ & $\begin{array}{l}\text { Values of } 0.02,0.15 \text { and } 0.35 \text { are } \\
\text { considered small, medium and } \\
\text { large, respectively. }\end{array}$ \\
\hline $\begin{array}{l}\text { Predictive Validity }\left(Q^{2}\right) \text { or Stone- } \\
\text { Geisser Indicator }\end{array}$ & $\begin{array}{l}\text { Evaluates the accuracy of the } \\
\text { adjusted model }\end{array}$ & $\mathrm{Q}^{2}>0$ \\
\hline Goodness of Fit (GoF) & $\begin{array}{l}\text { Global quality indicator of the } \\
\text { adjusted model }\end{array}$ & GoF $>0.36$ (suitable) \\
\hline Path coefficient $(\Gamma)$ & Evaluation of causal relationships & $\begin{array}{l}\text { Interpretation of the values in light } \\
\text { of theory }\end{array}$ \\
\hline
\end{tabular}

Note. Source: Hair, J. F., Jr., Black, W. C., Babin, B. J., Anderson, R. E. \& Tatham, R. L. (2009). Análise multivariada de dados (6a ed.). Porto Alegre: Bookman.

\section{Analysis of Results}

A total of 320 paper and pencil questionnaires were collected from HCS' users. Those 228 completed filled composed the sample, subsequently analyzed. This sample size was below the intended number (300 elements), but was still within the reasonable size for SEM (Hair et al., 2014). In terms of general profile of the sample: (a) family income mode was the bracket 881-1,300 reais; (b) $64 \%$ were female, $36 \%$ were male; (c) age has a great variation, ranging from 15 to 82 years. 


\section{Multivariate analysis}

The first step was to estimate the structural model $(\mathrm{n}=228)$, with all 26 items (measured variables), as a confirmatory factor analysis of the constructs Perceived Sacrifice (PS), Perceived Value (PV), Perceived Quality (PQ) and Satisfaction (SAT) towards HQS, and Individual Well-being (WB). The item PV16, relative to Perceived Value, carried a high load in the Perceived Quality construct, but it was kept in because it had a higher load in its own construct. To avoid high multicollinearity, estimated by the Variance Inflation Factor (VIF), the item "PQ6 - The staff of the clinic offer the personal attention that I need", was eliminated, as it had a low load and it was also lower than its loads on other constructs. After this pointwise modification, the Conceptual Model was reestimated by the PLS. Then, on the measurement models, all measured variable appear with loads higher than the threshold 0.70 .

To test the Discriminant Validity (Henseler, Ringle, \& Sinkovisc, 2009) among the latent variables, Table 2 presents the square root of the AVE for each latent on the diagonal as well as the bivariate correlations between each two latents. The square roots ( 1 in all cases) are always greater than the corresponding correlations on each column, signaling Discriminant Validity.

Table 2

Correlations and Average Variance Extracted Square Roots (Diagonal) of the Latent Variables

\begin{tabular}{cccccc}
\hline Construct & Well-being & $\begin{array}{c}\text { Perceived } \\
\text { Quality }\end{array}$ & $\begin{array}{c}\text { Perceived } \\
\text { Sacrifice }\end{array}$ & Satisfaction & Perceived Value \\
\hline Well-being & $\mathbf{1}$ & - & - & - & - \\
\hline Perceived Quality & 0.6239 & $\mathbf{1}$ & - & - & - \\
\hline Perceived Sacrifice & 0.4067 & 0.4615 & $\mathbf{1}$ & - & - \\
\hline Satisfaction & 0.5926 & 0.6788 & 0.3531 & $\mathbf{1}$ & - \\
\hline Perceived Value & 0.5747 & 0.6273 & 0.5895 & 0.483 & $\mathbf{1}$ \\
\hline
\end{tabular}

Note. Source: The authors.

Table 3 displays another indicators of model adjustment. The AVE is always above the threshold 0,5 , indicative of appropriate convergent validity on all them. Composite Reliability as well as the Cronbach's Alpha are always greater than 0,7 ; the latent variables are satisfactory in terms of reliability. The effects on the three endogenous constructs, estimated by the R2 coefficient, range from $35,1 \%$ (for Well-being) to 50,8\% (for Perceived Value); all them correspond to high effects (threshold 26\%).

Table 3

Convergent Validity, Reliability and other adjustment indicators for the latent variables in the Conceptual Model

\begin{tabular}{ccccc}
\hline Construct & AVE & Composite Reliability & Cronbach's Alpha & $\mathrm{R}^{2}$ \\
\hline Well-being & 0.631 & 0.895 & 0.854 & 0.351 \\
\hline Perceived Quality & 0.608 & 0.933 & 0.919 & 0.000 \\
\hline Perceived Sacrifice & 0.744 & 0.897 & 0.826 & 0.000 \\
\hline Satisfaction & 0.711 & 0.925 & 0.898 & 0.466 \\
\hline Perceived Value & 0.619 & 0.829 & 0.712 & 0.508 \\
\hline Note. Source:
\end{tabular}

Note. Source: The authors.

Table 4 contains the path coefficients and student $t$ test for the hypothesized relationships that comprise the Conceptual Model. p-values above 5\% were considered significant. The table shows both 
the original coefficient and mean coefficient of 500 resamples of the subjects in the sample (the latter being more robust). The H1's coefficient is significant [Perceived Sacrifice $\rightarrow$ Perceived Value, $\Gamma=0.381, \mathrm{t}_{(227)}=5.418, \mathrm{p}$-value $\left.<0.001\right]$, although it is positive instead of negative, on contrary to the previous logical specification; as so, H1 is not supported. H2's coefficient is not significant [Perceived Value $\rightarrow$ Satisfaction, $\Gamma=0.094, \mathrm{t}_{(227)}=1.297, \mathrm{p}$-value $>0.10$ ], depriving $\mathrm{H} 2$ of support. The remaining paths are significant, lending support to $\mathrm{H} 3$ [Perceived Quality $\rightarrow$ Satisfaction, $\Gamma=0.451, \mathrm{t}_{(227)}=7.331$, pvalue $<0.001$ ], H4 [Perceive Quality $\rightarrow$ Satisfaction, $\Gamma=0.620, \mathrm{t}_{(227)}=9.193$, p-value $<0.001$ ], and H5 [Satisfaction $\rightarrow$ Well-being, $\Gamma=0.596, \mathrm{t}_{(227)}=13.483$, $\mathrm{p}$-value $\left.\left.<0.001\right)\right]$. Next, Figure 3 chart out the main final structural results for the Conceptual Model.

Table 4

Final Structural Results for the Conceptual Model

\begin{tabular}{cccccccc}
\hline Hypo-thesis & Path & $\begin{array}{c}\text { Original } \\
\text { coefficient }\end{array}$ & $\begin{array}{c}\text { Mean } \\
\text { coefficient of } \\
500 \text { resamples }\end{array}$ & $\begin{array}{c}\text { Standard } \\
\text { Error }\end{array}$ & T test & p-value & Result \\
\hline H1 & $\begin{array}{c}\text { Perceived Sacrifice } \rightarrow \\
(-) \text { Perceived Value }\end{array}$ & 0.381 & 0.382 & 0.07 & 5.418 & 0.001 & $\begin{array}{c}\text { not } \\
\text { supported }\end{array}$ \\
\hline H2 & $\begin{array}{c}\text { Perceived Value } \rightarrow \\
(+) \text { Satisfaction }\end{array}$ & 0.094 & 0.098 & 0.073 & 1.297 & 0.196 & $\begin{array}{c}\text { not } \\
\text { supported }\end{array}$ \\
\hline H3 & $\begin{array}{c}\text { Perceived Quality } \rightarrow \\
(+) \text { Perceived Value }\end{array}$ & 0.451 & 0.453 & 0.062 & 7.331 & 0.001 & supported \\
\hline H4 & $\begin{array}{c}\text { Perceived Quality } \rightarrow \\
(+) \text { Satisfaction }\end{array}$ & 0.62 & 0.616 & 0.067 & 9.193 & 0.001 & supported \\
\hline H5 & $\begin{array}{c}\text { Satisfaction } \rightarrow \\
(+) \text { Well-being }\end{array}$ & 0.593 & 0.596 & 0.044 & 13.483 & 0.001 & supported \\
\hline
\end{tabular}

Note. Source: The authors.

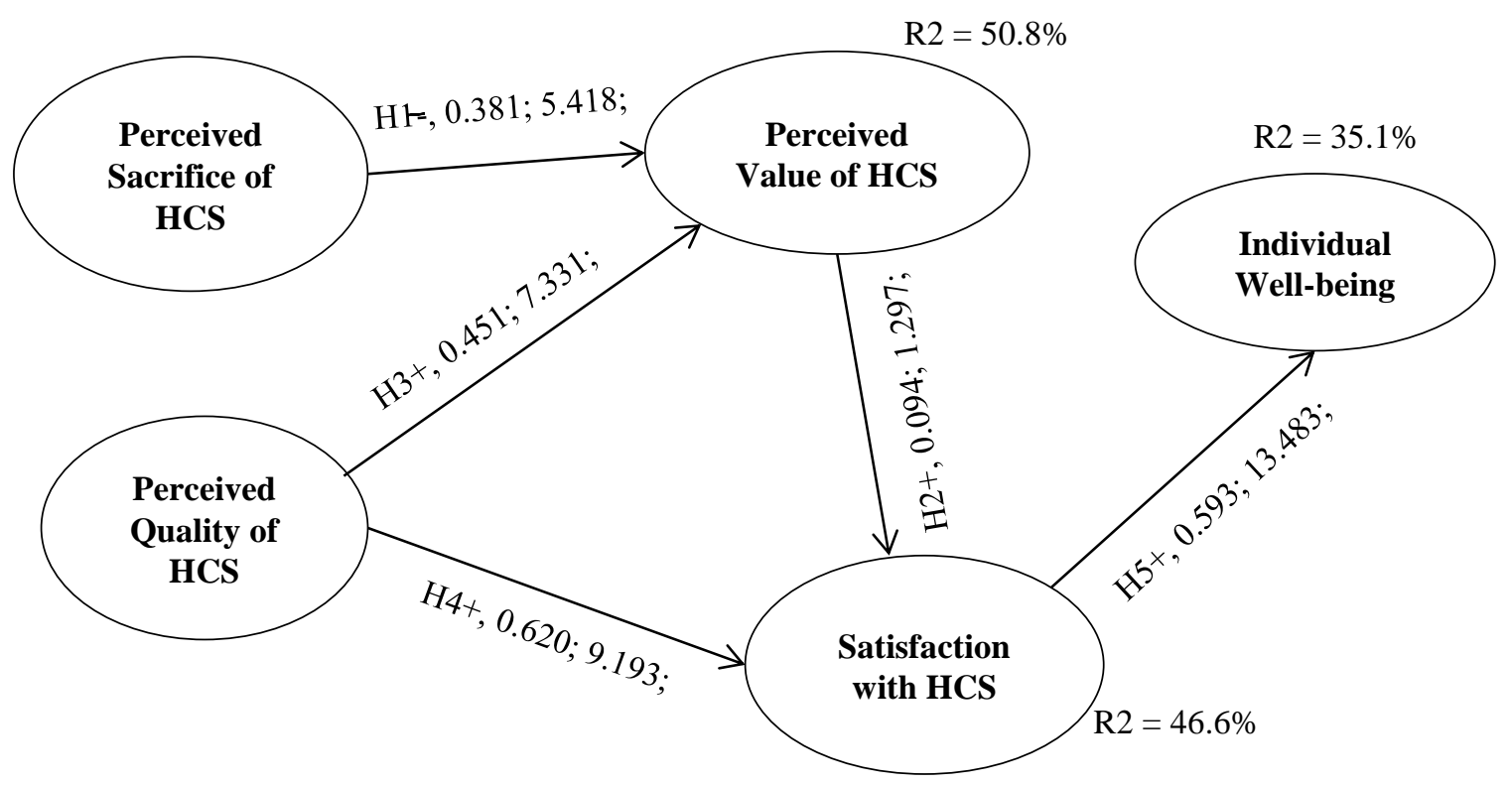

Figure 3. Final Structural Results For the Conceptual Model Source: The authors. 


\section{Discussion}

The SEM performed for the Conceptual Model supported three (H3, H4, H5) out of its five hypotheses. Now we discuss each of them.

The strongest path is that of Perceived Quality $\rightarrow$ Satisfaction (H4+), converging exactly to Akhade Jaju and Lahke (2013) on the same domain of HCS. On the opposite direction, it makes sense that the patient is pretty conscious that low quality HCS can and usually lead to more suffering and even the death, which, for this reason, triggers dissatisfaction. The definitions of Perceived Quality - e.g, the recognition by the user of the efforts to get things right, as necessary and appropriate for him/her (Pedroso \& Malik, 2012) - express how important it is in HCS. Although hard to be reached (Berry \& Bendapudi, 2007; Berry \& Mirabito, 2010), Satisfaction with HCS comes from previous or simultaneous recognition of Perceived Quality. It is not an easy shortcut, at all, as such Quality means excellent or superior HCS relatively to expectations and the competitors. Also, Perceived Quality is referred as difficult to be evaluated, but the subjects of our sample was able to evaluate it.

The second strongest path is that of Satisfaction $\rightarrow$ Individual Well-Being (H5+), confirming in a health context the generalized position of Prahalad (2010) about the life at the BoP. That result is also according to Anderson et al. (2013) as to the beneficial impact of services onto the society through wellbeing, accomplishing its transformative potential. Anyway, it is impressive that user's Satisfaction with an even short and simple HCS directly impact well-being, a broad construct. Maybe low-incomers like those in our sample are so deprived of assistance in general, that Satisfaction with any public health support entails a substantive experience, at the point of establishing a linear relationship between that construct and Well-being.

The third strongest path is that of Perceived Quality $\rightarrow$ Perceived Value (H3+). First, evaluating Perceived Quality of HCS is generally describe as a difficult task for patients in general, and one could expect that it would be even more difficulty for a low-incomer. Differently, it seems that low-incomers do evaluate such Perceived Quality on the dimensions and benefits that they can process as a nonprofessional. On generalized dimensions like reliability, responsiveness, assurance, empathy, and tangibles of the Servqual Scale (Parasuraman, Zeithaml, \& Berry, 1988). This characterization is confirmed by the effortless data collection and its frequency distribution for Perceived Quality, i.e., our sample succeed on evaluating Perceived Quality and consistently discriminated the HCS received on this construct; and these are requisites for a good statistical analysis. Second, perceived quality directly contributes to the numerator of the Perceived Value ratio. Third, based on the previous rationale, it makes sense that users of HCS (including those in our sample) establish a positive relationship of the type 'the greater (the lesser) the Perceived Quality, the greater (lesser) the Perceived Value'.

At the aggregated level, the Conceptual Model explains noteworthy $35,1 \%$ of the variance of Individual Well-Being; i.e., a little bit more than $1 / 3$ of such Well-Being depends on those three aforementioned exogenous constructs towards HCS!

Surprisingly, the path Perceived Sacrifice $\rightarrow$ Perceived Value (H1-) was significant but with a positive coefficient instead of the negative hypothesized, diverging to Brady et al. (2005) and all the services evaluation models included in their comparison. As the public HCS in Brazil are free of charge, their utilization directly entails only non-monetary costs, but these costs are often heavy on the journey until receiving HCS and heavier prior to an integral healing. Hence, it would make sense a negative link between Perceived Sacrifices and Perceived Value. On the contrary, according to our empirical results, we speculate that low-incomers develop an atypical posture in face of HCS, by which the more Sacrifices made (like the honor of a conquest), the more Perceived Value. Perhaps those customers reason and feel like the winners of a though competition, that eventually deserve and got the prize (i.e., HCS), when emerges an increased Perceived Value. Besides, our sample was totally composed by respondent that had just received HCS. Maybe for other patients, that did not obtain HCS, Perceived Sacrifices could exert the usual negative impact on Perceived Value, as no prize is gained. On the other 
side, it is conceivably that Perceived Sacrifice represents a complex construct for HCS' users; specially because they do not pay directly for them in a public clinic (which was the case in our population and sample). Complexity that could have generated problematic scores for the construct and restricted the subsequent relationship analysis. If inappropriate data is inputted to an equation, the output is unlikely to be a good representation of the investigated phenomenon.

The path Perceived Value $\rightarrow$ Satisfaction ( $\mathrm{H} 2+)$ was not supported. It can be that low-incomer users of HCS do not process a linear relationship between those two constructs. We guess there is a relationship between those constructs, though a nonlinear (curved) one, at least for one or more segments underlying our sample. However, the performed SEM captures only linear relationships. For instance, perhaps distinct segments in our sample could: (a) perceive very low value on a HCS (as a lot of sacrifice was necessary to obtain not so much benefits) but the derived benefits themselves could increase Satisfaction; (b) perceive very low value on a HCS (as a lot of sacrifice was necessary to get not so much benefits) and the ratio (benefits $\div$ sacrifices) could not increase Satisfaction. Then, the complete sample would not manifest the path described in $\mathrm{H} 2$.

\section{Conclusions}

To improve the understanding of the antecedents of well-being at the individual level, we substituted behavioral intentions for that construct on the best generalized service evaluations model, pointed out by Brady et al. (2005), based on logical rationale for each path here specified and integrated on a Conceptual Model. The aim was to test the impact of HCS evaluations on the well-being of lowincomers that had received primary care at a public clinic in São Paulo city. Going further, we divide this Conclusions on Implications and Directions for Future Research.

\section{Implications}

The services knowledge is advancing and the field is even becoming a science (Ostrom et al., 2010). However, in face of the richness of the theme of services to low-income populations (huge contingents spread across all countries, cities and regions), the research here reported helps (in spite of being only a tiny step) to understand the phenomena surrounding the links between HCS and well-being of those consumers. Consumers that are citizens often suffering a lot as a consequence of insufficient and misaligned HCS that the State in Brazil is constitutionally obliged to provide.

Providing appropriate HCS to the low-income population is one of the greatest challneges of the 21st Century. The Millennium Development Goals (MDGs), promoted by the United Nations Organization and agreed to by all the world's countries, triggered unseen efforts to meet the needs of the poorest. No less than four out of the eight MDGs deals directly with HCS (United Nations Organization, 2015). Improving their well-being depends on many macro factors, like innovation and low-cost technologies, public policy priorities, empowering local communities, and international cooperation. But that improvement also results from just primary HCS, as demonstrated by our research; that is really encouraging. Summing up, delivering HCS to the BoP that is perceived as Quality and generate Satisfaction seems to impact the Well-being that people.

HCS for the BoP comprises a huge market for companies and institutions capable to cater for its particular needs, that lead to Perceived Quality and Satisfaction, at the really low costs that government budgets can afford. All these organizations are called upon to find ways to serve those clients and to do so in a way that fulfills obligations towards a broader metric, i.e., Well Being. Well-being that is an evolution to analyze the consequences of services to consumers. It is relevant not only on an individual level, but also on a collective level, as it impacts family groups and communities. 
As the HCS can increase people's well-being at the BoP, we strongly recommend measuring and managing the constructs and he confirmed paths on our Conceptual Model, as a trail of transformative services to so many needy people (Ostrom et al., 2015).

Albeit so desirable that effects on well-being, it is not enough to just provide access to HCS, but it is imperative to delivery it in a such standard that Quality is Perceived by the user and he/she reach Satisfaction. This is an opportune exhortation to politicians and public administration executives, above all to those that are more interested in deceitful inaugurations than on delivering consistent solutions available day-by-day and aligned to the user's expectations. Nevertheless, once Perceived Quality Satisfaction with HCS is achieved, the effects on Well-being of the low-incomers is a barnstorming relationship from the human, social and - legitimately - political standpoints.

Even though we found a positive link between Perceived Sacrifice and Perceived Value (H1), it would not be effective to reinforce this way to increase the Well Being; and it would also be immoral. It is not significant the path from Perceived Value to Satisfaction and this last construct is the only immediate antecedent of Well Being. Notwithstanding, it is a social, political and moral duty for all those involved in delivering HCS to manage the sacrifices impinged on the BoP. Low-income consumers, who have fewer choices due to financial constraints, are likely to make greater sacrifices than other consumers to get what they need. Especially when the services' costs - like in our research are beard by the government. We guess that beyond a certain limit, higher perceived sacrifices could disembogue in personal revolt and social turmoil. Also, no matter how increased is Perceived Value as a consequence of higher Perceived Sacrifices, that construct does not influence Satisfaction, which is the antecedent of Well Being.

The health outcomes in Brazil improved overall between 1990 and 2016, but important health inequities remained (GBD 2016 Brazil Collaborators, 2018). However, since 2014, the severe economic crisis in Brazil have already constrained the Unified Health System (SUS) through increasing austerity (substantial budget cuts) (Doniec, Dall'Alba, \& King, 2018). The adverse implications can be seen since now and may exacerbate the historical socioeconomic inequalities in health care. On the contrary, our results recommend at least caution when cutting funds for HCS targeted to the BoP, as they directly impact theirs Well Being. Theoretical advances and empirical evidences on Well-Being should be taken into account on planning, implementing and controlling public and private services as a whole, and particularly with HCS, in search of real impact on people's Well-being (Rojas, 2015). That is our greatest expectation with this paper.

\section{Limitations and directions for future research}

The conclusions presented here apply to the sample studied in this study, i.e., cannot be extrapolated for other low-incomers users of HCS. For sure, further empirical studies are essential to reach a more solid demonstration of the relationship that comprise our Conceptual Model. More investigations should be undertaken on different types of HCS (especially on secondary and tertiary care) and on different states and countries. It is essential to reinforce or even modify the support to the antecedents of the Individual Well Being on the realm of Health Care. We also strongly recommend the fulfillment of comparative tests among our Model and competing models. On this direction, a good idea would be to start with the other three service evaluation models reported by Brady et al. (2005). Also relevant would be the analysis of our Conceptual Model, and alternatives models too, with middle and high income users of HCS.

The hypothesized links Perceived Sacrifice $\rightarrow$ Perceived Value (H1-) and Perceived Value $\rightarrow$ Satisfaction, not supported in our research, deserves sound attention. On them, we suggest an exploratory qualitative research design, to deeply probe into its meanings on the targeted population. Also the quantitative exam of curvilinear relationship between each pairs of construct would be important. 
Finally, our Conceptual Model with the sample explained (R2) substantive portions of the variance in the endogenous constructs: 50.8\% of Perceived Value of HCS, 46.6\% of Satisfaction with HCS, and $35.1 \%$ on Individual Well-Being. Looking on the other way round, it is necessary to search for other antecedents that would boost those explanation levels, at the same time trying to keep the model as parsimonious as possible.

\section{Referências}

Anderson, L., \& Ostrom, A. (2015). Transformative service research: Advancing our knowledge about service and well-being. Journal of Service Research, 18(3), 243-249. https://doi.org/10.1177/1094670515591316

Anderson, L., Ostrom, A. L., Corus, C., Fisk, R. P., Gallan, A. S., Giraldo, M., Mende, M., Mulder, M., Rayburn, S. W., Rosenbum, M. S., Shirahada, K., \& Williams, J. D. (2013). Transformative service research: An agenda for the future. Journal of Business Research, 66(8), 1203-1210. https://doi.org/10.1016/j.jbusres.2012.08.013

Barbosa, E. C. (2013). 25 anos do Sistema Único de Saúde: Conquistas e desafios. Revista de Gestão em Sistemas de Saúde, 2(2), 85-102. http://doi.org/10.5585/rgss.v2i2.51

Berry, L. L., \& Bendapudi, N. L. L. (2007). Health care a fertile field for service research. Journal of Service Research, 10(2), 111-122. https://doi.org/10.1177/1094670507306682

Berry, L. L., \& Mirabito, A. M. (2010). Innovative health care delivery. Business Horizons, 53(2), 157169. https://doi.org/10.1016/j.bushor.2009.11.002

Bhatnagar, N. E., \& Grover, M. (2014). Health care for the "Bottom of the Pyramid". Population Health Management, 17(1), 5-7. https://doi.org/10.1089/pop.2013.0036

Bitner, M. J., \& Brown, S. W. (2008). The service imperative. Business Horizons, 51(1), 39-46. https://doi.org/10.1016/j.bushor.2007.09.003

Bôas, B. V. (2018, outubro 9). Extrema pobreza avança e é recorde em 9 Estados. Valor Econômico, Recuperado de https://www.valor.com.br/brasil/5912587/extrema-pobreza-avanca-e-e-recordeem-9-estados

Boksberger, P. E., \& Melsen, L. (2011). Perceived value: A critical examination of definitions, concepts and measures for the service industry. Journal of Services Marketing, 25(3), 229-240. https://doi.org/10.1108/08876041111129209

Brady, M. K., Knight, G. A., Cronin, J. J., Jr., Tomas, G., Hult, M., \& Keillor, B. D. (2005). Removing the contextual lens: A multinational, multi-setting comparison of service evaluation models. Journal of Retailing, 81(3), 215-230. https://doi.org/10.1016/j.jretai.2005.07.005

Brazilian Market Research Association. (2016). Brazilian Criteria 2015 and social class distribution update for 2016. São Paulo: Associação Brasileira de Empresas de Pesquisa/Brazilian Market Research Association

Burroughs, J., \& Rindfleisch, A. (2002). Materialism and well-being: A conflicting values perspective. Journal of Consumer Research, 29(3), 348-370. http://doi.org/:10.1086/344429

Chin, W.W. (1998). Comentary: Issues and opinion on Structural Equation Modeling. MIS Quarterly, 22(1), vii-xvi. 
Chitolina, L., Foguel, M. N., \& Menezes-Filho, N. A. (2016). The impact of the expansion of the Bolsa Família Program on the time allocation of youths and their parents. Revista Brasileira de Economia, 70(2), 183-202. http://doi.org/10.5935/0034-7140.20160009

Cooper, D. R., \& Schindler, P. S. (2003). Métodos de pesquisa em administração (7a ed.). Porto Alegre: Bookman.

Cronin, J. J., Jr., Brady, M.K., Tomas, G., \& Hult, G. T. M. (2000). Assessing the effects of quality, value, and customer satisfaction on consumer behavior and intentions in service environments. Journal of Retailing, 76(2), 193-218. https://doi.org/10.1016/S0022-4359(00)00028-2

Dagger, T. S., \& Sweeney, J. C. (2006). The effect of service evaluations on behavioral intentions and quality of life. Journal of Service Research, 9(1), 3-18. https://doi.org/10.1177/1094670506289528

Deloitte. (2018, January 9). Deloitte global health care outlook: The evolution of smart health care. New York. Retrieved October 2, 2019, from https://www2.deloitte.com/global/en/pages/aboutdeloitte/articles/global-health-care-sector-outlook-working-towards-smart-health-care.html

Diener, E. (2010). SWLS translations. Retrieved January 22, 2017, from http://labs.psychology.illinois.edu/ ediener/SWLS.html

Diener, E., \& Biswas-Diener, R. (2001). Will money increase subjective well-being? A literature review and guide to needed research. Social Indicators Research, 57(2), 119-169. https://doi.org/10.1007/978-90-481-2350-6_6

Diener, E., Diener, M. (1995). Cross-cultural correlates of life satisfaction and self-esteem. Journal of Personality Social Psychology, 68(4), 653-663.

Diener E., Emmons, R. A, Larsen, R. J., Griffin, S. (1985). The satisfaction with life scale. Journal of Personality Assessment, 49(1), 71-75. https://doi.org/10.1207/s15327752jpa4901_13

Diener, E., Suh, M., Lucas, R.E. \& Smith, H.L. (1999). Subjective well-being: Three decades of progress. Psycological Bulletin, 125(2), 276-302. http://doi.org/10.1037/0033-2909.125.2.276

Diener, E., Inglehart, R., \& Tay, L. (2013). Theory and validity of life satisfaction scales. Social Indicators Research, 112(3), 497-527. https://doi.org/10.1007/s11205-012-0076-y

Donabedian, A. (1988). The quality of care: How can ir be assessed? JAMA The Journal of the American Medical Association, 260(12), 1743-1748. https://doi.org/10.1001/jama.260.12.1743

Doniec, K., Dall'Alba, R., \& King, L. (2018). Brazil's health catastrophe in the making. The Lancet, 392 (10149), 731-732. https://doi.org/10.1016/S0140-6736(18)30853-5

Fisk, R. P. P., Anderson, L., Bowen, D. E., Gruber, T., Ostrom, A., Patricio, L., Reynoso J., \& Sebastiani, R. (2016). Billions of impoverished people deserve to be better served: A call to action for the service research community. Journal of Service Management, 27(1), 43-55. https://doi.org/10.1108/JOSM-04-2015-0125

Freitas, H., Janissek, R., Moscarola, J., \& Baulac, Y. (2002). Pesquisa interativa e novas tecnologias para coleta e análise de dados usando o Sphinx ${ }^{\circledR}$. Porto Alegre: Sphinx.

Freitas, H., Oliveira, M., Saccol, A. Z., \& Moscarola, J. (2000). O método de pesquisa survey. Revista de Administração da USP, 35(3), 105-112.

Gallian, A. S., Jarvis, C. B., Brown, S. W., \& Bitner, M. J. (2012). Customer positivity and participation in services: An empirical test in a health care context. Journal of the Academy of Marketing Science, 41(3), 338-356. https://doi.org/10.1007/s11747-012-0307-4 
GBD 2016 Brazil Collaborators. (2018). Burden of disease in Brazil, 1990-2016: A systematic subnational analysis for the Global Burden of Disease Study 2016. The Lancet, 392(10149), 760775. https://doi.org/10.1016/S0140-6736(18)31221-2

Gebauer, H., \& Reynoso, J. (2013). An agenda for service research at the base of the pyramid. Journal of Service Management, 24(5), 482-502. https://doi.org/10.1108/JOSM-04-2013-0090

Giovanella, L., Mendoza-Ruiz, A., Pilar, A. D. C. A., Rosa, M. C. D., Martins, G. B., Santos, I. S., \& Machado, C. V. (2018). Sistema universal de saúde e cobertura universal: Desvendando pressupostos e estratégias. Ciência \& Saúde Coletiva, 23(6), 1763-1776. http://doi.org/10.1590/1413-81232018236.05562018

Goldschmidt, P. C. (1972). Marketing e o bem-estar da sociedade: Uma perspectiva para os países subdesenvolvidos. Revista de Administração de Empresas, 12(3), 7-15. http://doi.org/10.1590/S0034-75901972000300001

Gouveia, M. T. C. de S. (2004). O modelo de agência reguladora e a ANS: Construção do regime regulatório na saúde suplementar (Dissertação de mestrado). Escola Nacional de Saúde Pública. Rio de Janeiro, Fundação Oswaldo Cruz.

Hair, J. F., Jr., Black, W. C., Babin, B. J., Anderson, R. E. \& Tatham, R. L. (2009). Análise multivariada de dados (6a ed.). Porto Alegre: Bookman.

Hair, J. F., Jr., Hult, T. M., Ringle, C. M., \& Sarstedt, M. (2014). A primer on Partial Least Squares Structural Equation Modeling (PLS-SEM). Los Angeles: Sage.

Henseler, J., Ringle, C. M., \& Sinkovisc, R. R. (2009). The use of partial least squares path modeling in international marketing. Advances in International Marketing, 20, 277-319. http://doi.org/10.1108/S1474-7979(2009)0000020014

Heskett, J. L., Sasser, W. E., \& Hart, C. W. L. (1990). Service breakthroughs: Changing the rules of the game. New York: The Free Press.

Jurberg, C. (2008). Flawed but fair: Brazil's health system reaches out to the poor. Bulletin of the World Health Organization, 86(4), 241-320. http://doi.org/10.2471/BLT.08.030408 •

Kerk, G. v. de, \& Manuel, A. R. (2008). A comprehensive index for a sustainable society: The SSI - the sustainable society index. Journal of Ecological Economics, 66(2/3), 228-242. https://doi.org/10.1016/j.ecolecon.2008.01.029

Kerlinger, F. N. (1980). Metodologia da pesquisa em ciências sociais: Um tratamento conceitual. São Paulo: EPU.

Kobau, R., Sniezek, J., Zack, M. M., Lucas, R. E., \& Burns, A. (2010). Well-being assessment: An evaluation of well-being scales for public health and population estimates of well-being among US adults. Applied Psychology: Health and Well-being, 2(3), 272-297. https://doi.org/10.1111/j.1758-0854.2010.01035.x

Leclerc, F., \& Schmitt, B. H. (1999). The value of time in the context of waiting and delays. In M. Holbrook, Consumer value: A framework for analysis and research (pp. 28-42). London: Routledge.

Malhotra, N. K. (2009). Marketing research: An applied orientation (6th ed.). Upper Saddle River: Pearson.

Manchin, A. (2011, June 22). Low-income Britons struggle with their well-being. Gallup News. Retrieved February 2, 2019, from https://news.gallup.com/poll/148151/low-income-britonsstruggle-wellbeing.aspx 
Marchesini, L. (2018, fevereiro 5). Benefícios do Bolsa Família sustentam 21\% da população do país. Valor Econômico. Recuperado de https://www.valor.com.br/brasil/5306087/beneficios-do-bolsafamilia-sustentam-21-da-populacao-do-pais

Ministério da Saúde. (2012). Sobre a plataforma Brasil. Retrieved January 22, 2017, from http://plataformabrasil.saude.gov.br/login.jsf

Neri, M. (2012). De volta ao país do futuro: Crise européia, projeções e a nova classe média. Rio de Janeiro: Fundação Getulio Vargas.

Norma Operacional $N^{o} 001 / 20,13$. (2013). dispõe sobre a organização e funcionamento do Sistema CEP/CONEP, e sobre os procedimentos para submissão, avaliação e acompanhamento da pesquisa e de desenvolvimento envolvendo seres humanos no Brasil, nos termos do item 5, do Capítulo XIII, da Resolução CNS n 466 de 12 de dezembro de 2012. Brasília, Ministério da Saúde.

Oliver, R. L. (1993). Cognitive, affective, and attribute bases of the satisfaction response. Journal of Consumer Research, 20(3), 418-430. https://doi.org/10.1086/209358

Ostrom, A. L., Bitner, M. J., Brown, S., Burkhard, K. A., Goul, M., Smith-Daniels, V., Demirkan, H., \& Rabinovich, E. (2010). Moving forward and making a difference: Research priorities for the science of service. Journal of Service Research, 1(13), 436. https://doi.org/10.1177/1094670509357611

Ostrom, A. L., Parasuraman, A., Bowen, D. E., Patricio, L., \& Voss, C. (2015). Service research priorities in a rapidly changing context. Journal of Service Research, 18(2), 127-159. https://doi.org/10.1177/1094670515576315

Parasuraman, A., Zeithaml, V. A., \& Berry, L. L. (1988). SERVQUAL: A multiple-item scale for measuring consumer perceptions of service quality. Journal of Retailing, 64(1), 12-40

Pedroso, M. C., \& Malik, A. M. (2012). Cadeia de valor da saúde: Um modelo para o sistema de saúde brasileiro. Ciência e Saúde Coletiva, 17(10), 2757-2772. http://doi.org/10.1590/S141381232012001000024

Prahalad, C. K. (2010). A riqueza na base da pirâmide: Como erradicar a pobreza tendo lucro. Porto Alegre: Bookman.

Prahalad, C. K., \& Hart, S. L. (2002). The fortune at the Bottom of the Pyramid. Strategy + Business, 26(1), 1-14.

Resolução $n^{\circ} 466$ de 12 de dezembro de 2012. (2013, junho 13). Diretrizes e normas regulamentadoras de pesquisas envolvendo seres humanos. Brasília: Diário Oficial da União no 12, Seção 1, p. 59.

Ringle, C. M., Wende, S., \& Will, A. (2005). Smart PLS 2.0 M3. Hamburg: University of Hamburg.

Rojas, M. (2015). Poverty and People's Wellbeing. In: The fortune at the Bottom of the Pyramid Glatzer, W., Camfield, L., Møller, V., Rojas, M. (Eds.). Global handbook of Quality of Life: Exploration of well-being of nations and continents. Heidelberg: Springer Netherlands. 317-350.

Singh, J. (1991). Understanding the structure of consumers' satisfaction evaluations of service delivery. Journal of the Academy of Marketing Science, 19(3), 223-244. https://doi.org/10.1007/BF02726498

Singh, N. (2008). Decentralization and public delivery of health care services in India. Health Affairs, 27(4), 991-1001. 
Sirgy, M. J., Michalos, A. C., Ferriss, A. L., Easterlin, R. A, Patrick, D., \& Pavot, W. (2006). The qualityof-life (QOL) research movement: past, present, and future. Social Indicators Research, 76(3), 343-466. https://doi.org/10.1007/s11205-005-2877-8

Sirgy, M. J., M. Joseph Sirgy, Gurel-Atay, E., Webb, D., Cicic, M., Husic, M., Ekici, A., Herrmann, A., Hegazy, I., Lee, D.-J., \& Johar, J. S. (2012). Linking advertising, materialism and life satisfaction. Social Indicators Research, 107(1), 79-101. https://doi.org/10.1007/s11205-011-9829-2

Sirgy, M. J., Lee, D.-J. (2016). Work-life balance: A quality-of-life model. Applied Research in Quality Life, 11(4), 1059-1082. https://doi.org/10.1007/s11482-015-9419-6

Sustainable Society Foundation. (2017). Data - all countries: SSI 2016. The Hague. Retrieved October 2, 2018, from http://www.ssfindex.com/results/ranking-all-countries/

Sweeney, J. C., Danaher, T. S., Mccoll-Kennedy, J. R. (2015). Customer effort in value cocreation activities: Improving quality of life and behavioral intentions of health care customers. Journal of Service Research, 18(3), 318-335. http://doi.org/10.1177/1094670515572128

United Nations Organization. (2015). Millennium development goal 8: MDG Gap Task Force (Report 2015), New York, United Nations.

Urdan, A. T. (2001). A qualidade de serviços médicos na perspectiva do cliente. Revista de Administração de Empresas, 41(4), 44-55. http://doi.org/10.1590/S0034-75902001000400006

Vecina, G., Neto, \& Malik, A. M. (2012). Gestão em saúde. Rio de Janeiro: Guanabara Koogan.

Voss, G. B., Parasuraman, A., \& Grewal, D. (1998). The roles of price, performance, and expectations in determining satisfaction in service exchanges. Journal of Marketing, 62(4), 46-61. http://doi.org/10.2307/1252286

Witt, A. (1967). Saúde pública e o problema de classificação social. Revista de Saúde Pública, 1(2),172176. http://doi.org/10.1590/S0034-89101967000200004

Zambaldi, F., Costa, F. J., \& Ponchio, M. C. (2014). Mensuração em marketing: Estado atual, recomendações e desafios. Revista Brasileira de Marketing, 13(2), 1-26. http://doi.org/10.5585/remark.v13i2.2685

Zeithaml, V. A. (1988). Consumer perceptions of price, quality, and value: A means-end model synthesis of evidence. Journal of Marketing, 52(3), 2-22. http://doi.org/10.1177/002224298805200302

Zeithaml, V. A., \& Berry, L. L. (2003). Marketing de serviços: A empresa com foco no cliente. Porto Alegre: Bookman.

\author{
Authors \\ Lilian Tellini \\ Avenida Francisco Matarazzo, 612, Barra Funda, 01156-050, São Paulo, Brasil \\ E-mail address: liliantell32@gmail.com \\ Andre Torres Urdan \\ Avenida Francisco Matarazzo, 612, Barra Funda, 01156-050, São Paulo, Brasil \\ E-mail address: andre.urdan@gmail.com \\ Sonia Francisca Monken \\ Avenida Francisco Matarazzo, 612, Barra Funda, 01156-050, São Paulo, Brasil \\ E-mail address: sfmonken@hotmail.com \\ Flavio Santino Bizarrias \\ Avenida Francisco Matarazzo, 612, Barra Funda, 01156-050, São Paulo, Brasil \\ E-mail address: flavioxsp@ hotmail.com
}


Marcelo Moll Brandão

Av. Fernando Ferrari, 514, Goiabeiras, 29075-073, Vitória, ES, Brasil

E-mail address: mollmkt@gmail.com

\section{Contributions}

1st author: literature review, data collection, data analysis, writing.

2nd author: proposal of the research question and definition of the research design, final revision.

3rd author: insights and literature about health care.

4th author: sampling planning and statistical analysis.

5th author: insights and literature about consumer behavior and the Bottom of the Pyramid.

\section{Funding}

The authors reported that there is no financial support for the research in this article.

\section{Conflict of Interest}

The authors have stated that there is no conflict of interest.

\section{Plagiarism Check}

The RAC maintains the practice of submitting all documents approved for publication to the plagiarism check, using specific tools, e.g.: iThenticate.

\section{Supplementary Material}

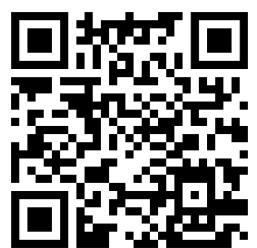

All data and materials have been made publicly available through the Mendeley platform and can be accessed at: Tellini, Profa Lilian; Urdan, André; Monken, Sonia; Bizarrias, Flavio; Brandão, Marcelo (2019), "Data for: "The Impact of Health Care Services Evaluations on Well-Being of Low-Incomers" published by RAC-Revista de Administração Contemporânea", Mendeley Data, v1. Retrieved from: http://dx.doi.org/10.17632/gn2jvckszx.1 